\title{
RECENZJA KSIĄŻKI „A NIECH SIĘ BRUDZĄ! NOWY SPOSÓB NA ZDROWIE TWOJEGO DZIECKA" (AUTORZY: R. BRETT FINLAY, MARIE-CLAIRE ARRIETA)
}

\author{
THE REVIEW OF THE BOOK 'LET THEM EAT DIRT: SAVING YOUR CHILD FROM AN OVERSANITIZED \\ WORLD' (AUTHORS: R. BRETT FINLAY, MARIE-CLAIRE ARRIETA)
}

\author{
Dorota Irena Prędkiewicz \\ studia doktoranckie z pedagogiki, Wydział Nauk Pedagogicznych \\ Dolnośląska Szkoła Wyższa we Wrocławiu
}

DOI: https://doi.org/10.20883/pielpol.2018.16

Kiedy przychodzi na świat dziecko, następuje totalna reorganizacja naszego życia, zmieniają się priorytety i sposób myślenia. Chcemy zapewnić maluchowi wszystko to, co najlepsze, aby jego rozwój przebiegał harmonijnie, bez zakłóceń i zbędnych niespodzianek. Młodzi rodzice zasypywani są poradnikami odnośnie pielęgnacji, rozwoju i wychowywania. Dobrą radą służą dziadkowie (czy zawsze najlepszą?), przyjaciele, znajomi. Często my - rodzice - poddajemy się ślepo panującym trendom, popadając ze skrajności w skrajność. Przykład: życie ekologiczne oczywiście w granicach rozsądku jest dobre, ale z chwilą, kiedy ekologia "decyduje” o życiu i zdrowiu malucha (odmowa podania dziecku witaminy $\mathrm{K}$ po porodzie, szczepień czy niedostarczanie właściwych witamin, mikroelementów w pożywieniu zgodnie z obowiązującym kalendarzem żywienia), jest wręcz zagrożeniem dla dziecka. Kolejną kroplą w morzu i kwestią sporną jest nasz stosunek do czystości. Pozwalać do woli brudzić się naszym dzieciom? Co zrobić ze smoczkiem, który upadł na ziemię? Czy kontakt ze zwierzętami jest dobry? No i kwestia wszechobecnych mikrobów: pomagają nam czy szkodzą? Na te pytania stara się odpowiedzieć wielu naukowców na całym świecie. Co ustalono? Odkrycia Pasteura, Listera, Cohna czy Kocha dowiodły, że chorób można uniknąć przez niedopuszczanie do kontaktu z mikrobami i masowe ich zabijanie. Jednak 200 lat później odkryto, że dążąc do nadmiernej czystości, zabijamy więcej mikrobów, niż jest to konieczne. Światowa Organizacja Zdrowia definiuje pojęcie higieny jako „warunki i praktyki, które sprzyjają zachowaniu zdrowia i zapobiegają rozprzestrzenianiu się chorób" [1]. Jednak współczesne społeczeństwa zachodnie doprowadziły dbałość o higienę do całkowitej skrajności. Czystość stała się bardziej obrzędem kulturowym niż potrzebą. Natomiast jej nadużywanie paradoksalnie doprowadziło do większej podatności na choroby cywilizacyjne (alergie, astma, zespół nadwrażliwości jelita grubego, autyzm, ADHD). Dr David Strachan (epidemiolog z Londynu) wysunął hipotezę, iż brak kontaktu z bakteriami i pasożytami w dzieciństwie hamuje prawidłowy rozwój układu odpornościowego i powoduje alergie (tzw. hipoteza higieniczna).

Naukowcy dr Brett Finlay, mikrobiolog i badacz mikrobiomu University of British Columbia w Kanadzie, oraz dr Marie-Claire Arrieta, mikrobiolog University of Clgary w Kanadzie, prowadzą badania nad rolą mikroflory w infekcjach, astmie czy niedożywieniu. Napisali wiele publikacji i artykułów w najważniejszych czasopismach naukowych (np.: „Gastroenterology", „Proceedings of the National Academy of Sciences"). Finlay i Arrieta są także autorami książki „A niech się brudzą! Nowy sposób na zdrowie twojego dziecka". Autorzy w swojej monografii w sposób zadziwiający, lecz poparty badaniami naukowymi udzielają porad, w jaki sposób dbać o odporność, zdrowie i rozwój psychomotoryczny naszych pociech. Całość podzielona jest na trzy zasadnicze części - pierwsza: „Mamy w sobie więcej z mikrobów niż z ludzi”, druga: „Dbanie o dzieci i ich mikroby”, trzecia: „Szkody uboczne”. Pomimo takiego podziału treść jest spójna, jedno wynika z drugiego. $\mathrm{Na}$ szczególną uwagę zasługuje druga część monografii. Nie sposób mieć odmienne zdanie niż autorzy na temat nadużywania antybiotyków (w czasie ciąży, podczas porodu lub tuż przed nim - profilaktycznie! - w czasie zakażeń wirusowych). Oczywiście nie można odbierać antybiotykom ich zasług. Wynalezienie antybiotyków to ogromny przełom dla ludzkości. Choroby, które zbierały śmiertelne żniwo, dzięki antybiotykom stały się uleczalne, poprawiły stan zdrowia, ale również przyczyniły się do długowieczności społeczeństw. Jednak jak we wszystkim obowiązuje umiar. Przykład: sprawą dyskusyjną jest stosowanie antybiotyków u dzieci z zapale- 
niem ucha. Holenderscy uczeni przeprowadzili badania, z których wynika, że na siedmioro dzieci przechodzących zapalenie ucha środkowego (leczonych antybiotykiem) tylko jedno odnosi korzyść z takiego postępowania. Zapalenie ucha poprzedza zazwyczaj zakażenie górnych dróg oddechowych (najczęściej wirusowe). Obecnie większość organizacji pediatrycznych opracowała wytyczne w postępowaniu w zapaleniu ucha środkowego, zalecając ostrożność w stosowaniu antybiotyków. Autorzy przestrzegają przed nadmiernym stosowaniem antybiotyków, które bezlitośnie zabijają nie tylko złe mikroby, ale i te dobroczynne (z greckiego: anti - „przeciw”, bioticos - „związany z życiem”, dosłownie „przeciw życiu”). Niewątpliwie z całą pewnością można się zgodzić z autorami w wielu kwestiach. Dotyczy to samego porodu (różnice w mikrobiocie noworodka urodzonego w sposób naturalny a urodzonego przez cięcie cesarskie), nadużywania antybiotyków, co w konsekwencji powoduje wiele skutków ubocznych, konieczności szczepienia dzieci, podawania witaminy D, która stanowi element regulujący mikrobiotę dziecka itd. Jednak w sposób bardzo krytyczny odnoszę się do kilku opisywanych przez Finlaya i Arrietę kwestii. Po pierwsze: „zaszczepianie” (proceder coraz bardziej popularny na całym świecie, także w Polsce) dziecka urodzonego przez cięcie cesarskie wydzielinami pochwowymi mamy zaraz po porodzie. Rzecz polega na tym, że kawałek sterylnej gazy wkładany jest do pochwy matki, następnie chowany do sterylnego naczynia, a zaraz po porodzie wnętrze jamy ustnej i skóra dziecka zostają nim wytarte. Sposób zaiste wielce niekonwencjonalny i budzący wręcz uczucie obrzydzenia (dobrze, że maluch tego nie pamięta). Dr Maria Dominguez-Bello zUniwersytetu Nowojorskiego dowodzi skutecznościpowyższej metody. Należy jednak zadać zasadnicze pytanie: czy „zaszczepianie” mikrobiotą pochwową matki jest bezpieczne dla dziecka? Po drugie: autorzy rozważają sytuację, w której dziecko opuszcza na ziemię smoczek. Co lepsze? Umycie brudnego smoczka w czystej, przegotowanej wodzie czy oblizanie go przez rodzica? Finlay iArrieta popierają tędrugąopcję. Powołują sięna szwedzkich naukowców, którzy na podstawie swoich badań doszli do wniosku, że dzieląc się z dzieckiem mikrobami z własnej jamy ustnej, rodzice wzmacniają układ odpornościowy dziecka (mniejsze ryzyko alergii). Właściwie to można przyjąć taką argumentację, ale czy pewnych obaw nie powinno budzić ryzyko przekazania dziecku przez rodziców bakterii wywołujących próchnicę? Po trzecie: obcowanie $z$ naturą, ze zwierzętami jest wielce dobroczynne dla dziecka (wzmacnia układ odpornościowy, znacznie obniża ryzyko alergii, astmy - zgoda), ale istnieją jakieś granice rozsądku! Opis (za pełną aprobatą autorów) 5-letniego dziecka, które umorusane po czubek głowy tym wszystkim, co można znaleźć na farmie, i konsumującego odchody kurze (prawdopodobnie w celach poznawczych), nie wywołuje u racjonalnie myślącego czytelnika uśmiechu, lecz obawę o zdrowie tego dziecka.

Książka napisana jest prostym, zrozumiałym językiem (pomimo trudnych zagadnień z dziedziny mikrobiologii). Dużym plusem monografii są prawdziwe historie rodzin, które borykają się z problemami zdrowotnymi dzieci (kolki, alergie, astma, autyzm itp.), dzieląc się swoimi doświadczeniami. To opowieść o świecie mikrobów, którego jesteśmy nierozłączną częścią. Walka z nimi nie wróży nic dobrego, ,....a nasze dążenie do wybicia w pień mikrobów może mieć poważne konsekwencje dla przyszłych pokoleń. Kto by pomyślał, że być może będziemy musieli wpisać bakcyle na listę gatunków zagrożonych?" (dr Martin Blaser) [2].

Lektura książki daje nowe, wręcz zadziwiająco rewolucyjne spojrzenie na problem czystości i higieny, wzmacniania naturalnej odporności i zdrowia oraz wspierania prawidłowego rozwoju dziecka od chwili poczęcia, poprzez okres ciąży i porodu, aż po pierwsze lata życia dziecka. Uważam, że publikacja, dostarczając nowych treści, wzbogaconych o dane z badań własnych autorów oraz ich obserwacji, stanowi cenny wkład w dziedzinę.

\section{Piśmiennictwo}

1. Finlay RB, Arrieta MC. A niech się brudzą! Nowy sposób na zdrowie twojego dziecka. Łódź: Feeria; 2017. 168-334.

2. Finlay RB, Arrieta MC. A niech się brudzą! Nowy sposób na zdrowie twojego dziecka. Łódź: Feeria; 2017. 144-334.

\author{
Adres do korespondencji: \\ Dorota Irena Prędkiewicz \\ ul. Strzegomska 55 \\ 53-611 Wrocław \\ tel. kom.: 668485278 \\ e-mail: stado5predki@op.pl \\ studia doktoranckie z pedagogiki, Wydział Nauk Pedagogicznych \\ Dolnośląska Szkoła Wyższa we Wrocławiu
}

